\title{
El patrimonio rural eclesiástico y su conservación sin uso en el antiguo señorío de Molina de Aragón (Guadalajara)
}

Valle Blasco Pérez | Dpto. de Conservación y Restauración de Bienes Culturales, Universitat Politècnica de València

URL de la contribución <www.iaph.es/revistaph/index.php/revistaph/article/view/4503>

Poblaciones de apenas unas pocas decenas de habitantes que recogen en sus términos municipales joyas patrimoniales de incalculable valor histórico y artístico: iglesias con retablos de riquísima ornamentación y conjuntos escultóricos en estados de conservación alarmantes.

Es la situación en la que se encuentra el patrimonio cultural mueble de las poblaciones que pertenecieron al antiguo señorío de Molina de Aragón, en Guadalajara. Es un área de la geografía española que, por la escasa densidad de población, se clasifica como demográficamente desierta, producto en parte del éxodo a las ciudades durante los años 60 y 70 del siglo $X X$, a su vez ocasionado por la falta de medios para el sustento de las familias que la abandonaron.

Y entonces, ¿cómo se explica que una zona tan deprimida económicamente "conserve" un patrimonio cultural tan sumamente rico?

El real señorío de Molina de Aragón tuvo su época de esplendor entre los siglos XII y XVIII, un extenso periodo en el que las condiciones económicas fueron variables, pero se mantuvo un nivel social y económico que principalmente al final de esta etapa, sobre los siglos XVI, XVII y XVIII, se vio impulsado por el comercio de la lana procedente de la cría de la oveja merina, que se extendió por gran parte de Europa y permeó también en las actividades económicas y comerciales que se mantenían con los territorios del continente americano. Esta fue una de las causas que permitieron que las zonas rurales, nunca demasiado grandes, mantuvieran un crecimiento poblacional limitado, pero de gran riqueza económica, y esto es lo que ha derivado en los tiempos actuales en poblaciones pequeñas, ya casi despobladas, con iglesias que

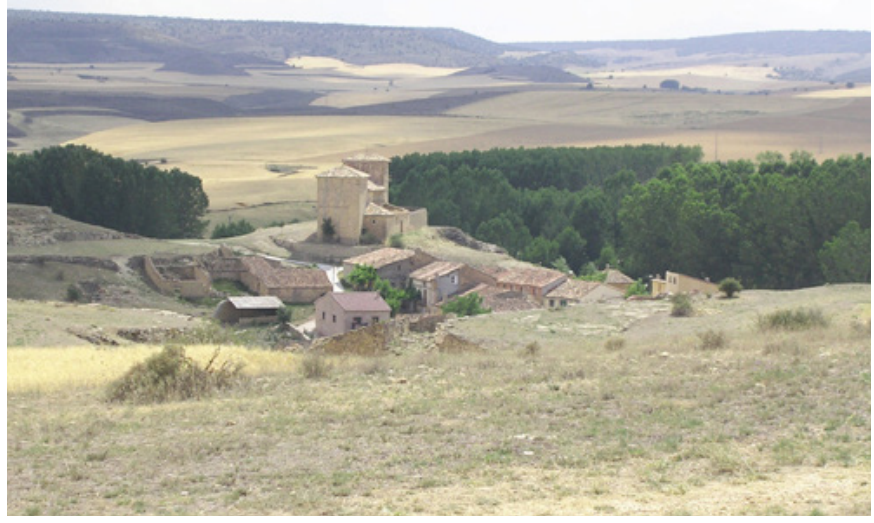

Iglesia de Pradilla (Guadalajara, España) | foto Valle Blasco Pérez

contienen retablos dorados que hoy en día se consideran de gran riqueza patrimonial, y fueron símbolo y ostento de la grandeza económica del pasado.

Podríamos hablar de Tartanedo, población de aproximadamente 90 habitantes, y cabecera municipal de cuatro pedanías de unos 10-20 habitantes cada una. En su núcleo principal tiene una de las iglesias más grandes y ricas de la comarca, consagrada a San Bartolomé, en la que se conserva un retablo mayor dorado de una calidad artística incalculable, y destaca entre sus bienes patrimoniales una colección pictórica de ángeles que con toda probabilidad fueron traídos desde el virreinato del Perú. La presencia de estas obras y este intercambio cultural se explicaría precisamente por las relaciones comerciales con los territorios del nuevo continente.

O podemos quizás reflexionar sobre el conjunto patrimonial de Fuentelsaz, población de apenas 89 habitantes. En este pequeño municipio se encuentra la iglesia de San Pedro, en cuyo interior se levanta un 
a debate ¿Hay patrimonio sin comunidad? Despoblamiento, turistificación y patrimonio cultural

| coordina Jaime Jover Báez

retablo mayor espléndido que tiene en su pared lateral derecha un lienzo que representa la imagen de la Virgen de Guadalupe, cuya presencia remite directamente por cuestiones estilísticas, además de la temática, a su procedencia novohispana. $Y$ no es el único ejemplo de piezas originiarias de los territorios de ultramar que se conservan en la iglesia de este pueblo. En un retablo lateral la escultura de un cristo novohispano preside la escena principal, e inmediatamente anexo a este, se levanta un retablo con marcadas connotaciones que no pueden negar el mismo origen, cuya existencia, igual que en el caso anterior, responde a las relaciones comerciales de las sexmas del real señorío de Molina de Aragón con los territorios de la corona española en el continente americano.

Y así podríamos seguir ilustrando con ejemplos que relatan cómo el pasado glorioso de estas pequeñas tierras sigue, aunque con dificultad, mostrando el esplendor que un día tuvo y contando la historia de las relaciones comerciales del pasado.

Pero, ¿qué pasa con estos preciosos bienes culturales, durmiendo su letargo entre los muros de modestas iglesias de pueblos sin habitantes? ¿qué les ocurre a estas imágenes, que ya no se rodean de devoción y devotos?

La vida de un bien cultural viene, como sabemos, determinada por su uso y disfrute por parte de las personas que les dan valor a diario con su apropiación, con su contemplación y en el caso de los objetos culturales eclesiásticos, con su devoción que motiva los cuidados oportunos para su mantenimiento. Y cuando las obras carecen de todo esto, su preservación entra en el declive más absoluto. Por eso, las obras a las que nos referimos mediante esta reflexión presentan un estado de conservación lamentable, cercano a su pérdida material total, y destacamos la material, porque la espiritual hace mucho tiempo que ya la perdió.

Algunos de estos conjuntos patrimoniales han sido restaurados como parte de un programa académico que tiene como finalidad formar en actividades prácti- cas a estudiantes de conservación y restauración de la Universitat Politècnica de València y contempla la recuperación de los bienes culturales de esta área rural con el apoyo de los correspondientes ayuntamientos. Pero una vez se concluyen las actividades de restauración, el patrimonio queda estabilizado material y estéticamente, $y$, sin embargo, siguen faltando los usuarios que lo revaloricen con su presencia y sus actos.

Lamentablemente en este caso el repoblamiento no es la solución, debido a que al tratarse de obras eminentemente religiosas católicas, lo que necesita este patrimonio albergado en pequeñas iglesias que apenas conservan fechas de culto, es quien las venere y les siga celebrando sus días festivos, cosa que actualmente es cada vez menos frecuente. Pero este es un problema al que tiende el patrimonio eclesiástico en general, no solo el de las zonas rurales, aunque a este último se le suma el abandono y el olvido en el que han caído estos pueblos.

Son muchas las reflexiones que genera este debate, que plantea una problemática que como ya se ha planteado, es de difícil solución por la carga emocional y devocional que acarrea. Quizás estas obras de incalculable valor histórico y artístico terminen sus días almacenadas en polvorientas sacristías, u olvidadas en los ruinosos altares mayores que, con más o menos dignidad, todavía presiden. O quizás su única esperanza de supervivencia material, y solo material, sea su reubicación en recintos expositivos dedicados a exhibir la memoria de un pasado artístico que ya se fue, aunque para ello se provocara su descontextualización y se las privara de sus ubicaciones originales donde solo cobraban sentido cuando las gentes les dirigían sus oraciones y les cantaban sus alabanzas. Pero esto ya sería tema para otro debate... 